\title{
A Proposed of Green Practices and Green Innovation Model in Malaysian Automotive Industry
}

Juriah Conding, Anis Fadzlin Mohd Zubir, Suzaitul Adwini Hashim \& Nurzatul Ain Sri Lanang Dept. of Accounting and Finance, Universiti Pendidikan Sultan Idris 35900 Tanjung Malim, Perak, Malaysia

Tel: 60-013-595-9391Ｅ-mail: juriahconding@yahoo.com

Nurul Fadly Habidin (Corresponding author)

Dept. of Management and Leadership, Sultan Idris Education University 35900 Tanjung Malim, Perak, Malaysia

Tel: 60-017-571-7027Ｅ-mail: fadly@fpe.upsi.edu.my

Received: August 3, 2012 Accepted: August 27, 2012

doi:10.5296/emsd.v1i2.2183～URL: http://dx.doi.org/10.5296/emsd.v1i2.2183

\begin{abstract}
Green practices are increasingly implemented in the automotive industry. Green practices characteristic have direct effects on green innovation. The associations among different of green practices (internal environmental management, technology integration, logistic management, customer focus, supplier focus) and reviewed which green practices can effect on green innovation (green product innovation and green process innovation). Thus, the main purpose of this study is to develop a model that the structural analysis of green practices and green innovation in Malaysian automotive industry. The conceptual model using Structural Equation Modelling (SEM) has been proposed. Base on the proposed conceptual model and reviewed, research hypotheses are being developed, the paper culminates with suggested future research work.
\end{abstract}

Keywords: Green practices, Green innovation, Environmental management, Structural equation model, Automotive 


\section{Introduction}

Nowadays, the role of continuous quality initiatives and green technology are most important within organization to improve their competitive advantage. To enhance competition, they need to apply multiply of Green Practices (GP) such as green supply chain management practices, green lean six sigma, and green balanced scorecard strategy and so on. Thus, automotive industry cans improve their competitive advantage through their GP to achieve their Green Innovation (GI). Therefore, this study makes to the understanding in a systematic and structured way of contexts of GP toward in GI especially in Malaysian automotive industry. Innovation is getting recognition from the top executives due to its strategic importance and globalizes competition, which has escalated the demand of better change and adoption of best practices through change in process. This study reviews whether implementation of GP has a positive influence toward GI.

GP has become a priority for most large organizations, and related to their GI has become increasingly common. This also support by Comoglio and Botta (2012) that the implementation of GP positively increases the number of companies employee committed and also involved and determinants higher investments towards environmental improvements especially to their innovation side. However, how can automotive industry achieve profitably improving the environmental and social impacts of their GI? And what role do GP play in the bigger picture of GI in the Malaysian automotive industry?

From for established companies, these are challenging questions about those with broad product offerings, and complex or resource intensive of GP. According to Azevedo et al., (2011) many managers appropriate and widely used to evaluate the influence of GP on company performance which GP have positive effects to enhance on quality, customer satisfaction and efficiency in company. Fortunately, new implementation of GP incorporating sustainability into the green product innovation and green process innovation are emerging and also enabling companies to move beyond compliance to cost reduction, competitive advantage, increased profitability, and at the same time companies can maximize their environmental performance.

Besides that, there is still considerable confusion surrounding the effect GP on GI in automotive industry. GI classified into three items as green product and green process and green managerial innovation in order to enhance environmental performance (Chiou et al., 2011; Tseng et al., 2012). According to Chen (2008) found that GI which is green product innovation and green manufacturing process innovation are influence positively effect on competitive advantage. This also support by Rao (2002) also found that GP adoption are lead to give positively impact on GI in company. Thus, this study stressed the important aspects by assessing the nature of the adoption of GP and GI toward to company's performance. We believe by exploring the GP will be benefit toward automotive industries in order to improve their GI. 


\section{I Macrothink}

\section{Literature Review}

Nowadays, GP is most important to create in their activities through green sustainable innovation in Malaysian automotive industries. Refer to Theyel (2000) that shows high levels of several GP for improving GI and performance. He also suggested that the adoption of GP such as total quantity management, training programs, $\mathrm{R} \& \mathrm{D}$, and evaluation of supplier are integrating with overall operations is more likely to improve company GI. GP are associated with GI that there are positively relates to both process and product innovations (Wagner, 2008; Chiou et al., 2011).

Generally, GP are the focal constructs in the theorized model with internal environmental management, technology integration, logistic management, customer focus and, supplier management as antecedents and green product innovation and green process innovation as consequences. Definitions of the constructs of GP incorporated in Table 1.

Table 1. Construct definitions

\begin{tabular}{ll}
\hline Construct & Operational definition \\
\hline Internal Environmental Management (IEM) & The practice of developing environmental as \\
& a strategic organizational imperative from \\
& senior and mid-level managers (Zhu et al., \\
& 2008) \\
& Technological integration can be defined as \\
& tacit knowledge sharing taking place between \\
Technology Integration (TI) & a buying and a supplying organization in \\
& strategic areas like product development, \\
& process reengineering, and technical training \\
& (Vachon and Klassen, 2006), the systems that \\
& have been modified and are used to monitor \\
& green practices and outcomes (Esty and \\
& Winston, 2006) \\
& The integrated life-cycle management of \\
green practices flowing from supplier, & through to manufacturer, customer, and \\
closing loop with reverse logistics (Vachon & and Klassen, 2006; Zhu et al., 2008) \\
Logistic Management (LM) & Cooperation with customers that affect the \\
design and development of their customer's \\
environmental practices (Zhu et al., 2008) \\
Cooperation with suppliers that purpose of \\
developing products that are environmentally \\
(Zhu et al., 2008)
\end{tabular}




\subsection{The Adoption of Green Practices (GP) in Malaysian Automotive Industry Context}

Several researches have surveyed that there are most studied of GP across among manufacturing process and firm sizes (Theyel, 2000; Rusinko, 2007; Zhu, et al., 2007; Chiou, et al., 2011; Green Jr, et al., 2012). However, none of these studies focused on this entire of automotive industry. The main goal of the green movement in automotive industry is to change industrial practices to reduces or eliminate environmental hazards (Stewart, 2001).

Several studies suggested the adoption of GP given positively effects on GI. For example, studied by Wagner (2008) indicating that GP execution is likely more systematic search processes for GI and seems to lead to learning processes triggered by the implementation of GP. The most important drivers of GI in automotive industry are consumer demand (performance, comfort, safety and fuel economy), international competition, and the most important thing is environmental objectives, regulations and impacts (Kuik, 2006). According to Yalabik and Fairchild (2011) that GP might have an adverse effect on the firm's environmental investment, and that support GI can be better alternative. Thus, adoption and implementation of GP in the automotive industry is most important to involved and focus in all aspects in several of products and processes innovation that have to provide a significant of green impact.

Furthermore, GP have led companies to incorporate more environmentally friendly practices to their product and process innovation (Gonzalez, 2008). Quality of management that positively relate to innovation through other practices that focusing to reduce or eliminate environmental hazards such as training, employee relations, supplier quality management, customer relations, and product and service design can efforts to establish and improve GP relate positively to innovative products or processes in both an existing market and emerging market (Kim et al., 2012). Besides that, Chan (2011) found that company cannot catch up if they are unable to comply with the environmental regulations; they need to incentive for moving green to gain the biggest slice of advantages. According to Mol et al., (2009) that the positive effect the introduction of GP is likely closer to product innovation and process innovation has opportunity for improvement in company performance. Thus, the GP implementation is positively associated with GI activities whether companies carry out environmentally related product and process innovations to enhance and improve their performances.

Therefore, based on results of previous exploratory research (Zhu et al., 2008; Vachon \& Klassen, 2006; Esty and Winston, 2006; Green, Jr, et al., 2012) that this research conceptualize GP adoption as associated with five different dimensions of GP including IEM, TI, LM, CF, and SF. The implementation of GP is expected to lead in improved GI as measured to reduce or prevent pollution can improve resource productivity and competitiveness (Rusinko, 2007).

\subsection{The Relationship between Green Practices (GP) and Green Innovation (GI)}

Nowadays, all company activities that focusing in GP now relate to GI. According to Amara et al., (2008) that $78.1 \%$ of firms have developed new or improved products and processes 
innovations, and majority it happened of SMEs innovate. Thus, GI particularly in product and their process are more important to decrease the environmental pollutions in automotive industry. GP standards can enhance an industry's incentive to introduce green products and technologies, and differentiating their products and lowering the cost of production through green product and green process innovations are necessary (Chiou, 2011; Tseng et al., 2012).

There are many studies proven that implementation of GP given positively related in GI especially in manufacturing process. There might be different GP that it can indicate in different GI in industry's performance improvements. Through Theyel (2000) studied that the products and processes of GI performance can be redesigned to industry to make more environmentally compatible, reducing the risk of product liability and criminal liability for polluting. Besides that, according to Montabon (2007) that in particular, GI that were attributed to environmental efforts were to be scored higher in industry performance. Similar with Chiou (2011) that green process and green product innovation are positively associated with firm's competitive advantage. This also supported by Rave (2011) that GP are considered for achieving higher on GI are likely to reduce pollution or the negative impacts of resource use and the green sustainability of the economy as a whole. In summary, GP has emerged with GI as an important that helps Malaysian automotive industry to develop strategies to gain more profit and industry's competitive advantage by lowering their environmental risks and impacts.

Generally, the adoptions of GP are more important to GI (Theyel, 2000). GI can have a major impact in reducing environmental burden of the industry (Zailani, 2011). As viewed a whole studies, there might be different GP that it can relate in different of GI improvements. Thereby, these study separately in different GI measures such as green product innovation and green process innovation performance as consequences for this study. There for, below shows definitions of GI measure incorporated in Table 2.

Table 2. Construct Definition

\begin{tabular}{ll}
\hline Construct & Operational definition \\
\hline Green Product Innovation (GPTI) & $\begin{array}{l}\text { Product that is related to environmental } \\
\text { innovation, including the innovation in } \\
\text { product that are new or that offer a significant } \\
\text { improvement on the basic characteristic, } \\
\text { technical specification, incorporated software } \\
\text { or any components or materials and the } \\
\text { product that introduced are involved in } \\
\text { energy-saving, pollution-prevention, waste } \\
\text { recycling, no toxicity, or green product } \\
\text { design, using less or non-polluting/ toxic } \\
\text { materials, improving and designing } \\
\text { environmentally friendly packaging for } \\
\text { existing and new products, recovery of }\end{array}$ \\
\hline
\end{tabular}


Green Process Innovation (GPSI)

company's end-of-life products and recycling (Chen et al., 2006; Santamaria et. al., 2012; Brunnermeier and Cohen, 2003; Chiou et al., 2011; Huang and $\mathrm{Wu}, 2010$ )

Process that assumed to happen when it has implemented new or significantly improved production processes, distribution new methods or support activities for its good and services and the process is related to energy- saving, pollution- prevention, waste recycling, or no toxicity, low energy consumption, recycle, reuse and remanufacture material and use of cleaner technology to make savings and prevent pollution (Chen et al., 2006; Santamaria et. al., 2012; Brunnermeier and Cohen, 2003; Chiou et al., 2011)

\section{Research Framework and Hypotheses Development}

The research framework of this study has suggested that GP is improving to GI in Malaysian automotive industry. The research framework is shown in Figure 1 below, is develop to investigate the relationships between GP (IEM, TI, LM, CF, and SF) and GI (GPTI and GPSI). This regulation is also thought to impact upon the levels of GP and GI in an industry. Therefore, the relationship of GP on GI in Malaysian automotive industry is based on literature review above and the research framework. The following hypotheses of the study have been developed:

$\mathbf{H}_{1:}$ There is a positive and direct significant relationship between GP and GI in Malaysian automotive industry

The hypotheses above were set up to be tested. These hypotheses will be stated based on a numbering system by $\mathrm{H}_{1}$. This style of hypothesis statement is chosen due to the nature of answering hypotheses using SEM methods.



Figure 1. Framework of the study

\section{A Proposed Research Model}

The hypotheses will tested by using data collect with measured variables are obtained from 
respondents in response to a set of questionnaire. Researcher will use SEM to test the hypotheses. The research model aims at analyzing the impact of the relationship between GP and GI for Malaysian automotive industries. This model is called mediating model as presented in Figure 2.

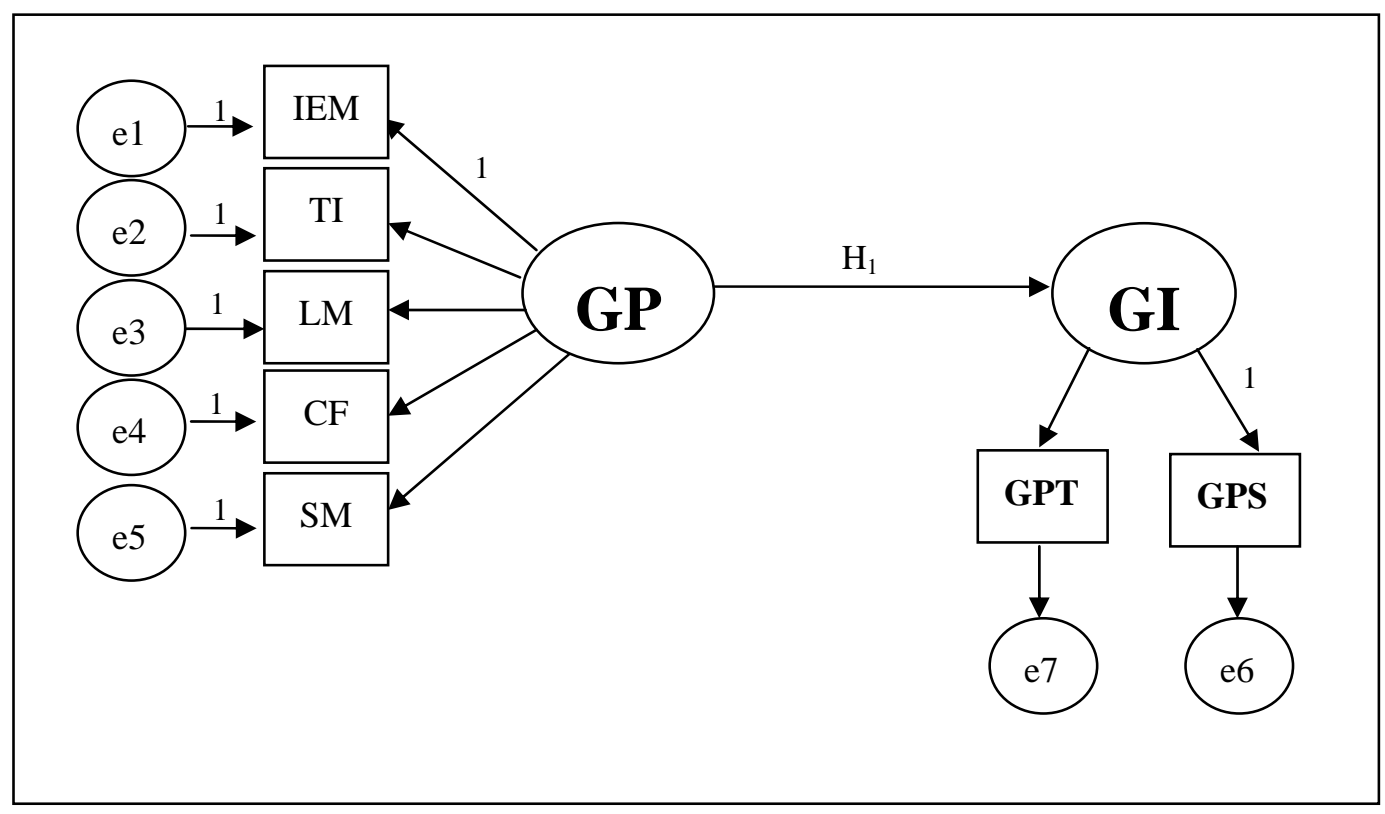

*Note: GP=Green Practices, GI=Green Innovation, IEM= Internal Environmental Management, TI= Technology Integration, $\mathrm{LM}=$ Logistic Management, $\mathrm{CF}=$ Customer Focus, $\mathrm{SM}=$ Supplier Management, GPTI= Green Product Innovation, GPSI= Green Process Innovation.

Figure 2. Model of the study

\section{Methodology}

Automotive industry is a highly dynamic, competitive and global industry (Kuik, 2006). Researcher was chosen automotive industry as a population of this study because the industry will face strong pressures and take initiatives in order to reduce the environmental burdens, needs to focus on green impacts, quality initiatives and performance measurement in this industry is very important (Gonzalez, 2008; Zakuan et al., 2009).

The population of this study comprised in Malaysian automotive industry. The sample should be a subset of the total population, which has the characteristics of the population. Therefore, samples were selected from the list of PROTON and PERODUA automotive suppliers. Structured questionnaire was using as a sampling method. To achieving the objectives of the study, the Malaysian automotive suppliers firms were selected as the population and the data was obtained from PROTON Vendor Association (PVA) and Kelab Vendor PERODUA (KVP). These lists of automotive suppliers consist of electrical, electronic, metal, plastic, rubber, and other automotive part.

The statistical Package for the Social Sciences (SPSS) version 17 was used to analyze the preliminary data and provide descriptive analyses about thesis sample such as means, 
standard deviations, and frequencies. SEM using AMOS 6.0 will use to test the measurement model. SEM techniques was utilize to perform the require statistical analysis of the data from the survey. Exploratory factor analysis, reliability analysis and confirmatory factor analysis to test for construct validity, reliability, and measurements loading were performed. Having analyzed the measurement model, the structural model was then tested and confirmed.

\section{Conclusion}

Referred to previous studies, they have been performed to identify critical success factors for successful implementation. However, no previous study had tried to investigate the relationships between GP and GI, especially in Malaysian automotive industry. Nowadays, GP and GI have become most important especially in Malaysian automotive industry to enhance the organization ability to become more environmentally effective to improve their performance especially in innovation. GI also is most important because it is needed to involve in local car manufacturers and automotive suppliers in their effort to increased green impact and green initiatives to the industry.

This study expected to provide valid and reliable for instrument and structural relationship model for GP constructs and GI measures. A conceptual model has been proposed to examine the relationships between GP and GI in the automotive industry in Malaysia. Based on proposed model and a previous study, research hypotheses are being developed. The next step of this study is to design a questionnare, which will be used for pilot study data collection in automotive industry in Malaysia.

\section{Acknowledgement}

The researchers would like to acknowledge the Ministry of Higher Education (MOHE) for the financial funding of this research thought Fundamental Research Grant Scheme (FRGS), and Research Management Centre (RMC) UPSI for Research University Grant (RUG).

\section{References}

Amara, N., Landry, R., Becheikh, N., \& Ouimet, M. (2008). Learning and novelty of innovation in established manufacturing SMEs. Technovation, 28, 450-463. http://dx.doi.org/10.1016/j.technovation.2008.02.001

Azavedo, S. G., Carvalho, H., \& Machado, V. C. (2011). The influence of green practices on supply chain performance: A case study approach. Journal Transportation Research Part E, 47, 850-871. http://dx.doi.org/10.1016/j.tre.2011.05.017

Brunnermeier, S. B., \& Cohen, M. A. (2003). Determinants of environmental innovation in US manufacturing industries. Journal of Environmental Economics and Management, 45, 278-293. http://dx.doi.org/10.1016/S0095-0696(02)00058-X

Chan, H. K. (2011). Green process and product design in practice. The 2011 International (European) Conference on Asia Pacific Business Innovation and Technology Management. Procedia: Social and Behavioral Sciences, 25, 398-402.

Chen, Y. S. (2008). The driver of green innovation and green image-green core competence. 
Journal Business Ethics, 81(3), 531-543. http://dx.doi.org/10.1007/s10551-007-9522-1

Chen, Y. S., Lai, S. B., \& Wen, C. T. (2006). The influence of green innovation performance on corporate advantage in Taiwan. J. Bus. Ethics, 67(4), 331-339. http://dx.doi.org/10.1007/s10551-006-9025-5

Chiou, T. Y., Chan, H. K, Lettice, F., \& Chung, S. H. (2011). Influence of greening the suppliers and green innovation on environmental performance and competitive advantage. Transportation Research Part E, 47, 822-836. http://dx.doi.org/10.1016/j.tre.2011.05.016

Comoglio, C., \& Botta, S. (2012). The use of indicators and the role of environmental management systems for environemtal performances improvement: a survey on ISO 14001 certified companies in the automotive sector. Journal of Cleaner Production, 20, 92-102. http://dx.doi.org/10.1016/j.jclepro.2011.08.022

Esty, D., \& Winston, A. (2006). Green to gold: How smart companies use environmental strategy to innovate, create value and build competitive advantage, Yale University Press, New Haven, CT.

Green Jr., K. W., Zelbst, P. J., Meacham, J., \& Bhadauria, V. S. (2012). Green supply chain management practices: Impact on performance. An International Journal, 17(3), 1-44.

Gregory, T. (2000). Management practices for environmental innovation and performance. Journal of Operations \& Production Management, 20(2), 249-266. http://dx.doi.org/10.1108/01443570010304288

Gonzalez, P., Sarkis, J., \& Adenso-Diaz, B. (2008). Environmental management system certification and its influence on corporate practices. International Journal of Operations \& Production Management, 28(11), 1021-1041. http://dx.doi.org/10.1108/01443570810910179

Huang, Y. C., \& Wu, Y. C. J. (2010). The effects of organizational factors on green new product success: Evidence from high-tech industries in Taiwan. Management Decision, 48(10), 1539- 1567. http://dx.doi.org/10.1108/00251741011090324

Kuik, O. (2006). Environmental innovation dynamics in the automotive industry. A case study in the framework of the project assessing in innovation dynamics induced by environment policy. Institute for Environmental Studies, Vrije University, The Netherlands.

Kim, D. Y., Kumar, V., \& Kumar, U. (2012). Relationship between quality management practices and innovation. Journal of Operations Management, 30, 295-315. http://dx.doi.org/10.1016/j.jom.2012.02.003

Mol, M. J., \& Birkinshaw, J. (2009). The sources of management innovation: When firms introduce new management practices. Journal of Business Research, 62, 1269-1280. http://dx.doi.org/10.1016/j.jbusres.2009.01.001

Montabon, F., Sroufe, R., \& Narasimhan, R. (2007). An examination of corporate reporting, environmental management practices and firm performance. Journal of Operations Management, 25, 998-1014. http://dx.doi.org/10.1016/j.jom.2006.10.003 
Rusinko, C. A. (2007). Green manufacturing: An evaluation of environmentally sustainable manufacturing practices and their impact on competitive outcomes. Transactions on Engineering Management, 54(3), 445-454. http://dx.doi.org/10.1109/TEM.2007.900806

Rave, T., Goetzke, F., \& Larch, M. (2011). The determinants of environmental innovations and patenting: Germany reconsidered. Institute for Economic Research at the University of Munich. [Online] Available: http://www.cesifo-group.de/portal/pls/portal/docs/1/1201429.PDF (July 31, 2012)

Rao, P. (2002). Greening the supply chain: a new initiative in South East Asia. International Journal of Operation and Production Management, 22(6), 632-665. http://dx.doi.org/10.1108/01443570210427668

Sanchez, C. M., \& Mckinley, W. (1988). Environmental regulatory influence and product innovation: The contingency effects of organizational characteristics. J. Eng. Technology Management, 15, 257-278. http://dx.doi.org/10.1016/S0923-4748(98)00017-4

Stewart, K. M. (2001). Trends, factors and public influences on the greening of industry: A review of the automobile and buildings sectors.

Santamaria, S., Nieto, M. J., \& Miles, I. (2012). Service innovation in manufacturing firms: Evidence from Spain. Journal Technovation, 32, 144-155. http://dx.doi.org/10.1016/j.technovation.2011.08.006

Theyel, G. (2000). Management practices for environmental innovation and performance. International Journal of Operations \& Production Management, 20(2), 249-266. http://dx.doi.org/10.1108/01443570010304288

Tseng, M. L., Wang, R., Chiu, A. S. F., Geng, Y., \& Lin, Y. H. (2012). Improving performance of green innovation practices under uncertainty. Journal of Cleaner Production, 1-12.

Vachon, S., \& Klassen, R. D. (2006). Extending green practices across the supply chain. International Journal of Operations \& Production Management, 26(7), 795-821. http://dx.doi.org/10.1108/01443570610672248

Wagner, M. (2008). Empirical influence of environmental management on innovation: Evidence from Europe. Ecological Economics, 66, 392-402. http://dx.doi.org/10.1016/j.ecolecon.2007.10.001

Yalabik, B., \& Fairchild, R. J. (2011). Customer, regulatory, and competitive pressure as drivers of environmental innovation. Int. J. Production Economics, 131, 519-527. http://dx.doi.org/10.1016/j.ijpe.2011.01.020

Zailani, S., Amran, A., \& Jumadi, H. (2011). Green innovation adoption among logistics service providers in Malaysia: An exploratory study on the managers' perceptions. International Business Management, 5(3), 104-113.

Zakuan, N. M. (2009). Structural analysis of total quality management, ISO/TS 16949 and organizational performance in Malaysian and Thailand automotive industry, PhD Thesis, 
Faculty of Mechanical Engineering, Universiti Technology Malaysia, Malaysia.

Zhu, Q., Sarkis, J., \& Lai, K. H. (2007). Green supply chain management: pressures, practices and performance within the Chinese automobile industry. Journal of Cleaner Production, 15, 1041-1052. http://dx.doi.org/10.1016/j.jclepro.2006.05.021

Zhu, Q., Sarkis, J., \& Kee-hung, L. (2008). Confirmation of a measurement model for green supply chain management practices implementation. Int. J. Production Economics, 111, 261-273. http://dx.doi.org/10.1016/j.ijpe.2006.11.029

\section{Copyright Disclaimer}

Copyright reserved by the author(s).

This article is an open-access article distributed under the terms and conditions of the Creative Commons Attribution license (http://creativecommons.org/licenses/by/3.0/). 